\title{
Identifying Resistance Gene Analogs Associated With Resistances to Different Pathogens in Common Bean
}

\author{
Camilo E. López, Iván F. Acosta, Carlos Jara, Fabio Pedraza, Eliana Gaitán-Solís, \\ Gerardo Gallego, Steve Beebe, and Joe Tohme
}

First, second, fourth, fifth, sixth, seventh, and eighth authors: Agrobiodiversity and Biotechnology Project; and third author: Bean Improvement Project, Centro Internacional de Agricultura Tropical (CIAT), A. A. 6713, Cali, Colombia.

Current address of C. López: Laboratoire Génome et Développement des Plantes, UMR 5096 CNRS, Université de Perpignan, 66860 Perpignan Cedex, France.

Accepted for publication 3 September 2002.

\begin{abstract}
López, C. E., Acosta, I. F., Jara, C., Pedraza, F., Gaitán-Solís, E., Gallego, G., Beebe, S., and Tohme, J. 2003. Identifying resistance gene analogs associated with resistances to different pathogens in common bean. Phytopathology 93:88-95.

A polymerase chain reaction approach using degenerate primers that targeted the conserved domains of cloned plant disease resistance genes ( $R$ genes) was used to isolate a set of 15 resistance gene analogs (RGAs) from common bean (Phaseolus vulgaris). Eight different classes of RGAs were obtained from nucleotide binding site (NBS)-based primers and seven from not previously described Toll/Interleukin-1 receptor-like (TIR)-based primers. Putative amino acid sequences of RGAs were significantly similar to $R$ genes and contained additional conserved motifs.

The NBS-type RGAs were classified in two subgroups according to the expected final residue in the kinase- 2 motif. Eleven RGAs were mapped at 19 loci on eight linkage groups of the common bean genetic map constructed at Centro Internacional de Agricultura Tropical. Genetic linkage was shown for eight RGAs with partial resistance to anthracnose, angular leaf spot (ALS) and Bean golden yellow mosaic virus (BGYMV). RGA1 and RGA2 were associated with resistance loci to anthracnose and BGYMV and were part of two clusters of $R$ genes previously described. A new major cluster was detected by RGA7 and explained up to $63.9 \%$ of resistance to ALS and has a putative contribution to anthracnose resistance. These results show the usefulness of RGAs as candidate genes to detect and eventually isolate numerous $R$ genes in common bean.
\end{abstract}

Disease resistance in plants usually occurs as a race-specific interaction between a resistance gene ( $R$ gene) in the host and a corresponding avirulence (Avr) gene in the pathogen (14). Using either map-based cloning or transposon tagging, several $R$ genes have been isolated from different plant species. Molecular characterization of these genes uncovered common sequence motifs, even though they confer resistance to a wide spectrum of pathogens (that is, viruses, bacteria, or fungi) $(6,19)$.

The presence of conserved domains permitted grouping of $R$ genes into at least four classes and to propose their possible function in the defense response as part of signal transduction pathways (6). The first class of $R$ genes contains Pto, a serinethreonine protein kinase, which confers resistance to bacterial speck disease in tomato (31). The second class includes the $C f$ family of tomato $R$ genes, which are effective against leaf mold and encode putative transmembrane receptors with extracellular leucine-rich repeats (LRR) domains $(13,21,49)$. A kinase group, associated with a receptor domain that results in a receptor-like kinase structure, characterizes the third class of genes, including $X a 21$, which confers resistance to rice bacterial blight (47). A nucleotide binding site (NBS) and a stretch of LRRs that characterize most of the functionally described $R$ genes make up the fourth class, examples of which are $N$ of tobacco, $L 6$ of flax, and

Corresponding author: J. Tohme; E-mail address: J.Tohme@cgiar.org

Equal contributions were made by the first two authors.

Nucleotide and amino acid sequence data have been submitted as GenBank Accession Nos. AF084026 and AF478170 to AF478183.

Publication no. P-2002-1115-01R

(C) 2003 The American Phytopathological Society
RPP5 and RPS2 of Arabidopsis spp. (8,27,34,39,55). They also have an NBS upstream domain, which is either a region containing coiled coils $(\mathrm{CC})$ or a Toll/Interleukin-1 receptor-like region (TIR; so named because of its homology with the cytoplasmic domain of the corresponding proteins in Drosophila spp. and mammals).

$R$ genes are clustered in the genome of several species, as shown by genetic and molecular studies. They display an apparent multiallelic structure or group as genetically separable loci. Examples of such complex resistance loci are found in flax (14), lettuce (57), barley (22), and common bean (18). Moreover, different genes within the same cluster that determine resistance to diverse pathogens have been reported in tomato $(12,53)$. Thus, $R$ genes are thought to be functionally and evolutionary related. The sequences of several $R$ gene clusters from rice (46), tomato (40), lettuce (32), Arabidopsis spp. (37), and common bean (18) have shed light on the molecular mechanisms leading to their evolution.

Based on sequence similarity between $R$ genes, a method using degenerate primers to target the conserved motifs has been successfully employed to isolate resistance gene analogs (RGAs) from potato (29), soybean $(23,58)$, rice (30), Arabidopsis spp. (1), lettuce (45), common bean $(18,44)$, and other monocotyledonous and dicotyledonous species. Many of the reported RGAs also were arranged in clusters and showed segregation with known resistance specificities. Degenerate oligonucleotide primers have been designed mainly from conserved amino acids in a few NBS motifs (P-loop and "kinase" or "GLPL" motifs). New, well-conserved NBS motifs have been proposed $(33,38)$, but the use of other domains has been limited.

The study of disease resistance in common bean (Phaseolus vulgaris) is important because it is a major staple crop that is highly susceptible to diseases such as anthracnose, angular leaf 
spot (ALS), and Bean golden yellow mosaic virus (BGYMV). Anthracnose is caused by the hemibiotrophic fungus Colletotrichum lindemuthianum, and is the most important fungal disease of bean throughout the world (42). ALS, caused by the fungus Phaeoisariopsis griseola, is a serious disease in tropical and subtropical countries (9). BGYMV is economically important in Latin America, and is caused by a geminivirus transmitted by the whitefly Bemisia tabaci (16).

Studies reporting sources of resistance to anthracnose (2) and ALS (9) had been concerned primarily with race-specific resistance that follows the gene-for-gene model. However, these fungi have exhibited considerable pathogenic variation that prevented durable resistance of single Phaseolus vulgaris lines under field conditions with sufficient disease pressure. Partial or complete resistance genes then were suggested as a probable source of durable resistance (20). Similarly, screening of germ plasm revealed only partial (low to moderate) resistance levels to BGYMV in a few accessions (16), again indicating that resistance to BGYMV is controlled largely by additive genes (2). Subsequently, genes for resistance to BGYMV were combined from several sources to obtain high levels of resistance.

Recent efforts to better understand bean disease resistance at the molecular level have led to (i) correlations between $R$ gene molecular evolution and host-pathogen gene-for-gene coevolution processes at the population level; the correlations were a result of identifying a major cluster containing $R$ genes efficient against $C$. lindemuthianum and RGAs from different gene pools of common bean (18); (ii) and evidence for partial resistance against anthracnose and quantitative trait loci (QTL) co-localization with "candidate genes" of resistance (17). RGAs also have been found to underlie some of the $R$ gene clusters for bean rust (44). Clustering of $R$ genes has been detected at $U r-5$, a locus that confers resistance to rust and contains eight tightly linked genes that behave as a single dominant independently assorting gene block (48).

In this article, we describe the identification of a relatively large set of RGAs from $P$. vulgaris, employing polymerase chain reaction (PCR) with degenerate primers based on conserved motifs of cloned $R$ genes. We not only used the primers designed by Leister et al. $(29,30)$ to amplify the conserved motifs of the NBS domain, but we also designed a downstream NBS primer (Motif1) to target a more complete and specific region. We also used another primer combination that had not been used for this purpose and which matches the TIR domain to isolate another type of putative resistance genes. Eight RGAs were identified as being associated with QTL for partial resistance to anthracnose, ALS, and BGYMV. A new major cluster of RGAs is reported along with two identified previously.

\section{MATERIALS AND METHODS}

Plant materials. A population of $\mathrm{F}_{9}$ plants from 87 recombinant inbred lines (RILs) was derived from a cross developed at Centro Internacional de Agricultura Tropical (CIAT) between G19833 (Andean genetic pool) and DOR364 (Mesoamerican genetic pool), which have contrasting responses to different iso- lates of anthracnose, ALS, and BGYMV. This population had been used to construct a linkage map (7), which was linked to the core mapping population described by Freyre et al. (15) by common restriction fragment length polymorphism (RFLP) markers.

The 87 RILs had been tested previously for resistance to ALS, anthracnose, and BGYM. Two Andine isolates (3COL and 260COL) and two Mesoamerican isolates (30CRI and 12MEX) of Phaeoisariopsis griseola, the ALS fungus, were inoculated as conidial suspensions by spraying onto the first fully expanded trifoliate leaf according to Pastor-Corrales et al. (41). Similar procedures were used to evaluate anthracnose resistance except that seedlings were inoculated instead of adult plants, with six isolates of $C$. lindemuthianum, the anthracnose fungus (5DOM, 235COL, 289COL, 20COL, 43COL, and 77CRI). Data for resistance to BGYMV were provided by J. S. Beaver (Department of Agronomy and Soils, University of Puerto Rico).

Degenerate primers and PCR conditions. Primers (Table 1) were designed from the conserved motifs P-loop and GLPLAL of the NBS domain according to Leister et al. (29). We designed an antisense primer (Motif1) from the conserved NBS sequence RNBS-D (33) of the $R$ genes $N$ (tobacco), L6 (flax), and RPP5 (Arabidopsis spp.), which contain the N-terminal TIR domain. As RNBS-D distinguished TIR and non-TIR NBS sequences (33), it became obvious that Motif1 would amplify NBS sequences associated with N-terminal TIR domains. Additionally, the TIR domain itself of $N, L 6$, and RPP5 was compared and two conserved regions from the Toll/IL-1R superfamily (19) were used to design a new set of primers (TIR1 and TIR5).

DNA was extracted from leaf tissues, as described by Tohme et al. (52). PCR reactions were performed for both parents in a total volume of $50 \mu \mathrm{l}$ containing $50 \mathrm{ng}$ of genomic DNA, $1 \times$ PCR buffer, $2.5 \mathrm{mM} \mathrm{MgCl} 2,0.2 \mathrm{mM}$ dNTPs, $0.1 \mu \mathrm{M}$ of each primer, and 2.5 units of Taq polymerase (Invitrogen Life Technologies, Carlsbad, CA). Cycling conditions were initial denaturation at $93^{\circ} \mathrm{C}$ for $2 \mathrm{~min}$, followed by 35 amplification cycles $\left(93^{\circ} \mathrm{C}\right.$ for $45 \mathrm{~s}, 45^{\circ} \mathrm{C}$ for $45 \mathrm{~s}$, and $72^{\circ} \mathrm{C}$ for $1 \mathrm{~min} 20 \mathrm{~s}$ ) and a final extension step at $72^{\circ} \mathrm{C}$ for $10 \mathrm{~min}$ before holding at $4^{\circ} \mathrm{C}$.

Cloning the PCR products. PCR products were separated by electrophoresis in a $1.2 \%$ low-melting-point agarose (Invitrogen) gel. Each expected band was eluted and purified with Wizard PCR-Prep columns (Promega Corp., Madison, WI). PCR-purified products were cloned into the pGEM-T easy vector system (Promega Corp.) and transformed in Escherichia coli DH5 $\alpha$ cells by electroporation, following Gibco-BRL instrutions. Approximately 40 clones derived from each expected band of both parents were randomly picked. Plasmids were extracted, using a lysis-byboiling miniprep protocol, and grouped by restriction digest patterns, using 4-bp cutting enzymes.

Sequence analysis. Clones from each restriction group were sequenced, using the Dye Terminator Cycle Sequencing Kit and an Applied Biosystems Prism 377 DNA sequencer (Perkin-Elmer Applied Biosystems), and edited with Sequencer (Genecodes, Ann Arbor, MI). Database searches were performed with the BLASTX (3) algorithm. Comparisons between sequences were done using CLUSTAL W (50).

TABLE 1. Degenerate primers used to isolate resistance gene analogs in common bean

\begin{tabular}{llll}
\hline Domain, motif & Primer $^{\mathrm{a}}$ & \multicolumn{1}{c}{ Sequence $\left(5^{\prime} \rightarrow 3^{\prime}\right)$} & Reference \\
\hline $\begin{array}{l}\text { Nucleotide binding site } \\
\text { GGVGKTT }\end{array}$ & S2 & GGI GGI GTI GGI AAI ACI AC & 29 \\
GLPLAL & AS1 & CAA CGC TAG TGG CAA TCC & 29 \\
& AS3 & IAG IGC IAG IGG IAG ICC & 29 \\
FLDIACF & Motif1 & GAA GCA IGC GAT GTC IAG GAA & This work \\
$\begin{array}{l}\text { Toll/Interleukin-1 receptor } \\
\text { (D/E)VFLSF }(\mathrm{R} / \mathrm{S}) \mathrm{G}\end{array}$ & & & This work \\
PVFYDVDP & TIR1 & GAI GTN TTY TTI TCI TTY AGI GG & This work \\
\hline
\end{tabular}

${ }^{a}$ Motif1, TIR1, and TIR5 are names adapted from the corresponding regions described by Hammond-Kosack and Jones (19). 
RFLP analysis. To visualize RFLPs, different clones were used as probes to hybridize filters containing digested genomic DNA prepared as follows: approximately $4 \mu \mathrm{g}$ of genomic parental DNA was digested with a set of five restriction enzymes (EcoRI, EcoRV, XbaI, HindIII, and DraI), according to the manufacturer's instructions (Invitrogen). Digests were separated on $0.9 \%$ gels by performing electrophoresis at $1 \mathrm{~V} \mathrm{~cm}^{-1}$ for $14 \mathrm{~h}$. The gel was blotted to Hybond $\mathrm{N}^{+}$membranes (Amersham Pharmacia Biotech, Piscataway, NJ), and the blots hybridized to ${ }^{32} \mathrm{P}-\mathrm{ATP}$-labeled DNA probes made by random priming (Amersham Pharmacia Biotech). After overnight hybridization at $65^{\circ} \mathrm{C}$, the blots were washed once in a solution of $2 \times \mathrm{SSC}(1 \times \mathrm{SSC}$ is $0.15 \mathrm{M} \mathrm{NaCl}$ plus $0.015 \mathrm{M}$ sodium citrate) and $0.1 \%$ sodium dodecyl sulfate (SDS) for $10 \mathrm{~min}$, then in $1 \times \mathrm{SSC}$ and $0.1 \%$ SDS for $20 \mathrm{~min}$ at the same temperature. Autoradiography was carried out for 2 to 6 days at $-80^{\circ} \mathrm{C}$ with an intensifying screen.

RFLP segregation was evaluated in the 87 RILs $-\mathrm{F}_{9}$ plants from the cross G19833 $\times$ DOR364. Developed markers were added to the G19833 × DOR364 linkage map developed at CIAT (7) using MAPMAKER software (version 2.0) (26).

QTL detection. Associations between RGA markers and QTL for resistance in common bean were tested by a simple linear regression of disease scores on marker genotype class means, using the single-marker analysis function of the QGENE 3.05 software (35). The amount of phenotypic variance explained by each RGA was obtained from the regression coefficient $\left(r^{2}\right.$ value) and associations were considered significant if the $P$, based on linear regression, was less than 0.002 (25).

\section{RESULTS}

Amplification with degenerate primers and sequence analysis of PCR products. To isolate RGAs in bean, we used four combinations of degenerate primers (Tables 1 and 2) on genomic DNA from two bean genotypes. Although some amplifications showed multiple band patterns, only fragments of the expected size (Table 2) were cloned. In initial experiments, fragments of sizes other than the expected also were cloned, but sequencing revealed that they were not homologous with $R$ genes (data not shown).

Approximately 100 clones were sequenced. A GenBank search, performed with the BLASTX algorithm and using clone sequences from combinations I to III (Table 2), resulted in

TABLE 2. Assayed primer combinations used to isolate resistance gene analogs in common bean

\begin{tabular}{|c|c|c|c|}
\hline Combination & Primers & $\begin{array}{l}\text { Expected size } \\
\text { (bp) }\end{array}$ & Classes obtained \\
\hline I & $\mathrm{S} 2+\mathrm{AS} 3$ & $\approx 500$ & RGA1, RGA2, RGA3 \\
\hline II & $\mathrm{S} 2+\mathrm{AS} 1$ & $\approx 500$ & RGA2 \\
\hline III & S2 + Motif1 & $\approx 680$ & RGA4 $\rightarrow$ RGA8 \\
\hline IV & TIR1 + TIR5 & $\approx 300$ & RGA9 $\rightarrow$ RGA15 \\
\hline
\end{tabular}

homology with the NBS of $R$ genes or with other RGA sequences recently cloned from other plant species, using similar PCR-based approaches. However, sequences from combination IV were homologous with the TIR domain from $R$ genes used to design the primers and from putative disease $\mathrm{R}$ protein sequences from Arabidopsis spp. identified through the annotation process of its genome sequence. Our report is the first on isolating TIR-type RGAs, using a PCR-based approach.

Clones from combinations I and II were grouped in three classes of RGAs (RGA1, RGA2, and RGA3). This low frequency of distinct RGAs prompted us to design combination III to more efficiently isolate new RGAs. It used an antisense primer (Motif1) from the conserved NBS sequence RNBS-D (33) of the $R$ genes $N$ (tobacco), L6 (flax), and RPP5 (Arabidopsis spp.). RNBS-D is located downstream the GLPLAL motif. Thus, combination III amplified a longer fragment of $680 \mathrm{bp}$ and produced five new classes of RGAs (RGA4 to RGA8) (Table 3). Multiple alignments between the eight RGA classes and three $R$ genes showed that RGAs possess two additional conserved motifs (kinase-2a and kinase-3), present in $R$ genes and different from those used to design the primers (Fig. 1).

Different RGAs were classified by pairwise comparisons of their deduced amino acid sequences and those of the NBS of known $R$ genes (Table 3 ). We used a $55 \%$ identity threshold value to determine those RGA sequences that belonged to the same family (45). Identities between classes were equivalent to those between different $R$ genes, although this was not the case for the pairs RGA1-RGA2 and RGA4-RGA5, which were very similar but not identical (55 and 52\% deduced amino acid identity, respectively). They were considered to be distinct classes because their hybridization pattern revealed differences that were reflected in map locations (see below). To make consistent sequence comparisons, only the region between the P-loop and GLPLAL motifs was used. The regions corresponding to the primers S2, AS1, and AS3 were not included, either, because their genomic sequences are not yet known for the clones.

The expected 280-bp band was cloned from combination IV, which targeted the TIR domain of $R$ genes. Deduced amino acid sequences of TIR-type RGAs were compared and assembled in seven new classes (RGA9 to RGA15) (Table 4). These RGAs also showed an internal conserved motif (TIR-2) (33) of $R$ genes not used to design degenerate primers (Fig. 2). Identities between TIR-type RGAs and the TIR domain of $R$ genes are higher than in the case of the NBS (Table 4). This is the result of comparing shorter sequences. Thus, a threshold value greater than the one used for the NBS-type RGAs is necessary to classify the TIR-type sequences.

RFLP mapping of RGAs. Different RGAs were used as RFLP probes to detect corresponding loci on 87 recombinant inbred lines (RILs, $F_{9}$ plants) from the cross G19833 × DOR364. RGA3, RGA8, RGA11, and RGA13 were monomorphic. Seven classes (classes 3, 5, 6, 8, 9, 11, and 13) detected single copy sequences, whereas the other eight classes showed complex (4 to 7 bands)

TABLE 3. Pairwise comparisons of nucleotide bind site-type resistance gene analogs (RGAs) from common bean with cloned resistance genes ${ }^{\mathrm{a}}$

\begin{tabular}{|c|c|c|c|c|c|c|c|c|c|c|}
\hline Class & RGA2 & RGA3 & RGA4 & RGA5 & RGA6 & RGA7 & RGA8 & L6 & $\mathrm{N}$ & RPS2 \\
\hline RGA1 & 55 & 12 & 10 & 15 & 15 & 8 & 14 & 13 & 18 & 25 \\
\hline RGA2 & $\ldots$ & 12 & 10 & 13 & 15 & 8 & 16 & 15 & 12 & 23 \\
\hline RGA3 & $\ldots$ & $\ldots$ & 13 & 6 & 11 & 12 & 7 & 12 & 5 & 28 \\
\hline RGA5 & $\ldots$ & $\ldots$ & $\ldots$ & $\ldots$ & 36 & 27 & 30 & 24 & 27 & 19 \\
\hline RGA6 & $\ldots$ & $\ldots$ & $\ldots$ & $\ldots$ & $\ldots$ & 30 & 32 & 32 & 30 & 16 \\
\hline RGA7 & $\ldots$ & $\ldots$ & $\ldots$ & $\ldots$ & $\ldots$ & $\ldots$ & 32 & 26 & 25 & 14 \\
\hline RGA8 & $\ldots$ & $\ldots$ & $\ldots$ & $\ldots$ & $\ldots$ & $\ldots$ & $\ldots$ & 28 & 37 & 16 \\
\hline
\end{tabular}

${ }^{\mathrm{a}}$ Values correspond to the percent identity of the deduced amino acid sequences. 
hybridization patterns. The RFLP pattern was different between classes, as predicted from sequence identities.

A total of 19 loci from 11 RGA classes could be mapped (Fig. $3)$ on 8 of the 11 linkage groups of common bean. Only one or two loci were mapped from the complex patterns in classes RGA1, RGA2, RGA7, RGA12, and RGA14 because not all bands could be resolved. Some of the RGA loci detected were tightly linked or cosegregated.

Association between molecular markers and resistance. The single-marker analysis by linear regression showed that QTL for resistance to anthracnose, BGYMV, and ALS were linked to RGAs from classes 1, 2, 6, 7, 9, 12, 14, and 15, which constituted half of the sequences isolated. These RGAs explained between 9.6 and $63.9 \%$ of the variance in resistance.

Some high $r^{2}$ values were obtained, suggesting the presence of major genes implicated in resistance to anthracnose and ALS.
Thus, two polymorphic DNA fragments from RGA1 were at a 9-cM interval and were associated with resistance to the anthracnose isolate 43COL. The phenotypic variations explained by these RGAs $\left(r^{2}\right)$ were 41.4 and $23.2 \%$. In the same manner, RGA7 was associated with a QTL for resistance to the ALS isolates 30CRI and 12MEX, and explained 47.1 and $63.9 \%$ of the phenotypic variance, respectively. It is noteworthy that the phenotypic variations explained by RGA1 and RGA7 were the highest in the regions were they mapped.

RGA7 was associated with resistance to different races of the same pathogen. This case also was present in RGA9 and RGA12 for ALS and in RGA2 for anthracnose. RGA2a was located in linkage group 04B in the same region of the PRLB and PRLJ family of RGAs isolated by Geffroy et al. (18) and linked to several anthracnose resistance specificities. Here, it is associated with resistance to a different anthracnose isolate (5DOM, $r^{2}=$

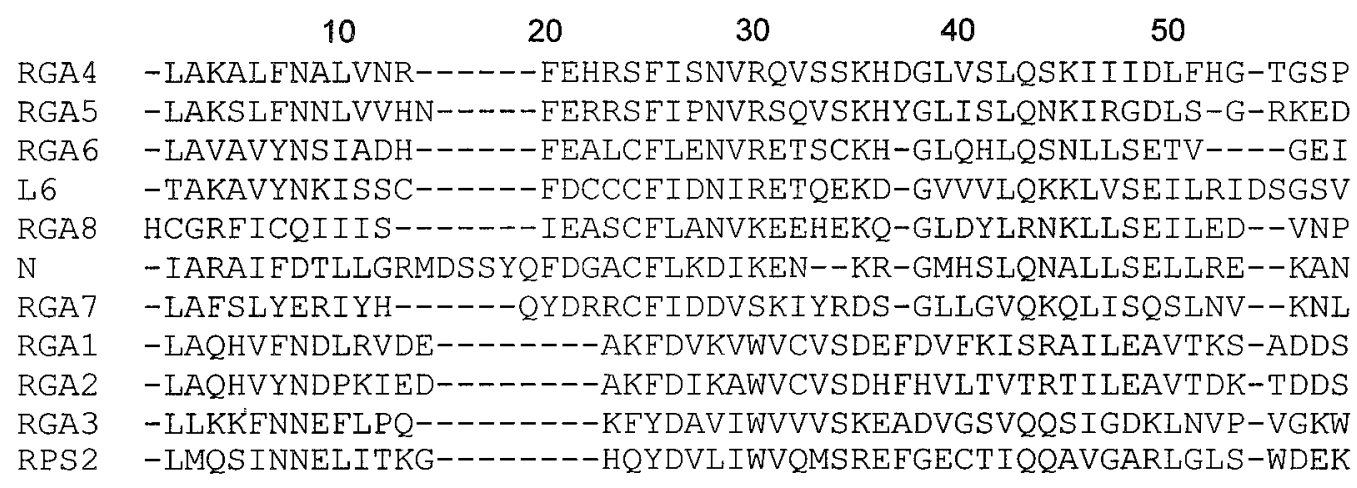

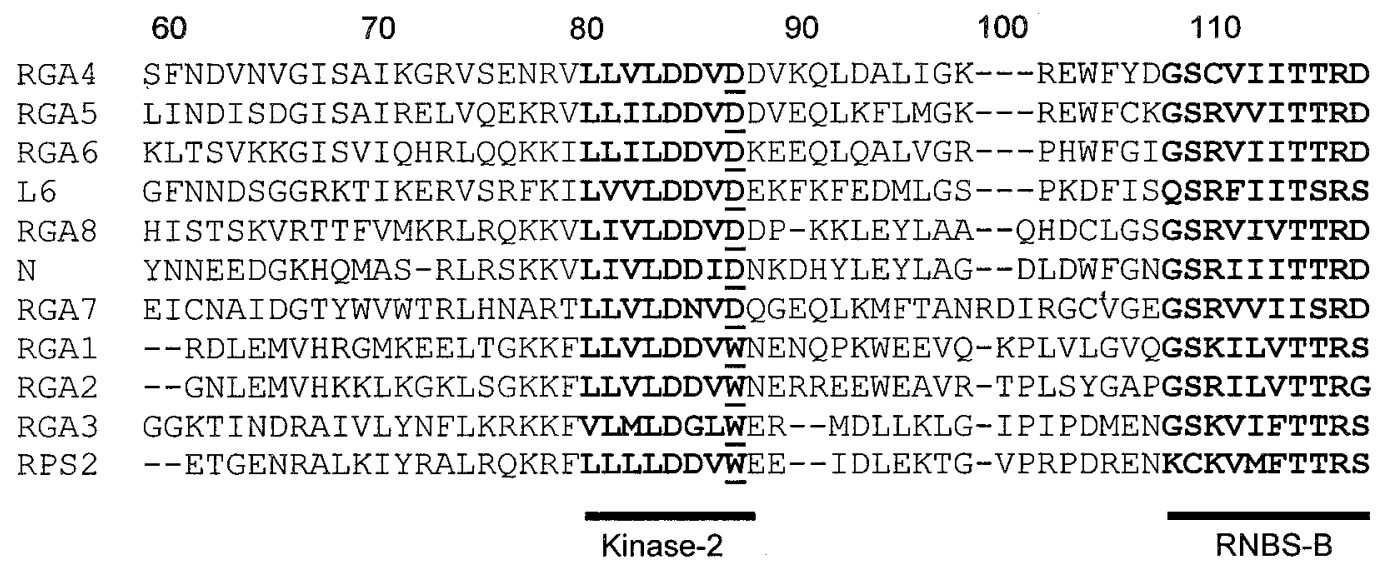

$\begin{array}{llllll}120 & 130 & 140 & 150 & 160 & 170\end{array}$

RGA4 TQVLTQNHVN--ELYEVKGLYASEAQELFSYHALRRNKPPD--NLLSLSEKI ISLTG

RGA5 KEILTESYVD--VHYEVKELEFSQGMELFCFHAIRRKEPAE--GFLDLSKQIVEKTG

RGA6 KQLLKCHGVK--RTYEVKELNEENALELLTWKAFKFENFDP--SYKDVLNLAVTYAS

L6 MRVLGTLNENQCKLYEVGSMSKPRSLELFSKHAFKKNTPPS--YYETLANDVVDTTA

RGA8 KHVLSRG-VD--AIYEVKGLSLHHAVRLFSLNSFGKTYPER--GFEMLSKQAVDHAN

N KHLIEK--ND--IIYEVTALPDHES IQLFKQHAFGKEVPNE--NFEKLSLEVVNYAK

RGA7 EHILKTHGVD--DVYQVQLLSWENAVQLFCRNAFKVNYILD--DYEELAREVLSHAQ

RGA1 KEVASTMRSE---EYSLQQLQEDDCWKLFAKHAFRGDCTQLNPECKKIGMKIVKKCK

RGA2 EKVASNMRSK---VHLLKQLEEDECWKVFANHAFKDGDHEFNDELKVIGRRIVEKCD

RGA3 MEVCRNMEANR--CIKVECLAQEEAFELFREKVGEETLNSH-PEIFPLAQILAKECQ

RPS2 IALCNNMGAEY--KLRVEFLEKKHAWELFCSKVWRKDLLES-SSIRRLAEI IVSKCG

Fig. 1. Alignment of the putative amino acid sequences of RGA1 to RGA8 from common bean and the nucleotide binding site of the resistance genes $N$ from tobacco, L6 from flax, and RPS2 from Arabidopsis spp. using CLUSTAL W. Residues in bold are part of internal conserved motifs as determined by Meyers et al. (33). The final residue in the kinase-a motif, which can be used to predict the presence of the Toll/Interleukin-1 receptor-like domain, is underlined. The regions homologous to the primers are not included. 
0.15). RGA2b cosegregated with RGA1a, which is itself associated with resistance to anthracnose isolate 43COL.

In other cases (RGA2a, RGA6, RGA7, and RGA14), the same RGA showed association with resistance to different pathogens. As stated above, RGA7 explained the greatest proportion of resistance to ALS. However, it also contributed to resistance to two isolates of anthracnose (43COL, $r^{2}=0.242$; 5DOM, $r^{2}=0.12$ ). RGA2a shared Andean and Mesoamerican partial resistances to anthracnose and BGYMV $\left(r^{2}=0.137\right)$. In effect, resistance to the anthracnose isolate 5DOM has been identified in the Andean parent G19833 while resistance to BGYMV has been detected in the Mesoamerican parent DOR364.

\section{DISCUSSION}

In this work, we isolated 15 classes of RGAs from common bean, using a PCR-based approach with degenerate primers that targeted the conserved motifs of the NBS and TIR domains from different plant $R$ genes. The isolated sequences showed high homology with previously isolated $R$ genes. Eight were associated with QTL for resistance to anthracnose, BGYMV, and ALS. Therefore, these RGAs are candidates for encoding $R$ genes or are suitable to detect $\mathrm{R}$ loci. This approach also has been successfully applied to other plants such as Arabidopsis spp., lettuce, pea, rice, potato, and soybean $(1,23,29,30,45,51,58)$.

The analysis of the NBS domains of different $R$ genes and RGAs of NBS type suggest classification into either TIR or nonTIR linked sequences $(33,38)$. The first are characterized by the presence of an aspartic acid residue (D) at the final portion of the kinase-2 motif. Examples of these are the genes $N$ and L6. In contrast, the non-TIR sequences have a tryptophan residue (W) in the same position and include RPS2, RPMI, and $I 2 C$-2. Based on this criterion, our classes RGA1, RGA2, and RGA3 are predicted to be non-TIR-containing sequences (Fig. 1).
Additionally, two domains within the NBS distinguish the two groups of NBS sequences (33). One of them (RNBS-D motif) has been proposed as a new target of degenerate primers to specifically isolate NBS sequences without N-terminal TIR domains. RNBS-D also is conserved enough among TIR-containing sequences that we were able to use a novel primer (Motif1) to exclusively isolate RGAs of the TIR-group (classes RGA4 to RGA8) which contain the aspartic acid residue (D) characteristic of the group (Fig. 1).

RGAs from the NBS type showed 5 to $55 \%$ amino acid identities to cloned $R$ genes and between them. This level of similarity is equivalent to that shown between cloned $R$ genes. In fact, low levels of identities are obtained when NBS sequences of the TIR type are compared with those of the non-TIR type. Grouping was made using a stringent 55\% threshold (45). However, in our case, we did have classes with amino acid identities near the threshold (RGA1-RGA2 and RGA4-RGA5), making it difficult to establish if they were members of the same group. Hybridization patterns and map locations were useful in distinguishing between RGA4 and RGA5.

RGA1 and RGA2 were a particular case. Their hybridization patterns were very similar, even under stringent post-hybridization washes. Such similarity indicates that they may share a physical location, as suggested by the co-segregation of RGAla and RGA2b at the bottom part of linkage group 11. However, they also showed different bands, which corresponded to another map location at linkage group 4 for RGA2a. Therefore, RGA1 and RGA2 could be members of a large and diverse family that is located in at least two different genomic regions as duplicated sequences.

Using the primers designed from the conserved TIR domain of the genes $N, L 6$, and RPP5, we obtained a new type of RGAs from bean (RGA8 to RGA15). We also successfully isolated TIR RGAs from cassava but not from rice (data not shown), thus

TABLE 4. Pairwise comparisons of Toll/Interleukin-1 receptor-type resistance gene analogs (RGAs) from common bean with cloned resistance genes ${ }^{\mathrm{a}}$

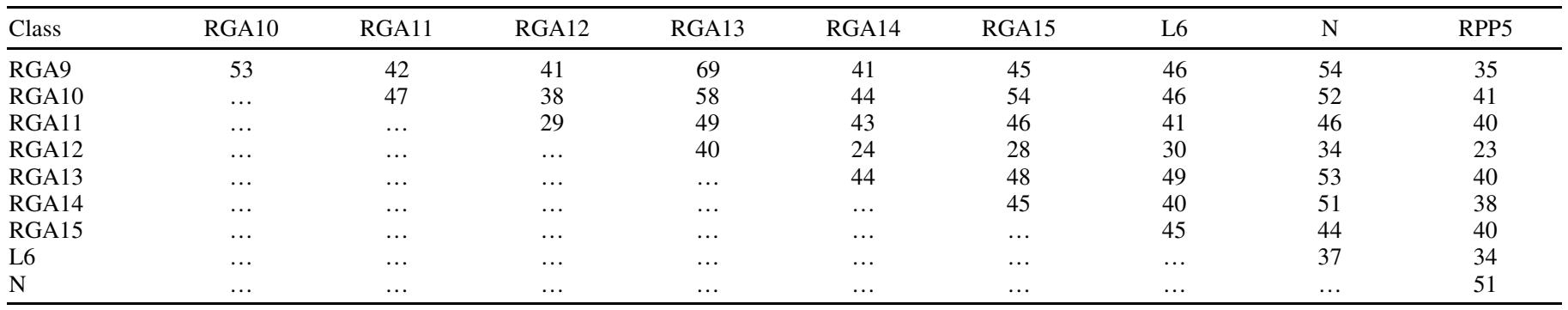

a Values correspond to the percent identity of the deduced amino acid sequences.

10

20

30

40

50

60

70

80

RGA9

RGA13

RGA10

$\mathrm{N}$

RGA14

RPP 5

L 6

RGA11

RGA 15

RGA12 EDTRKNEVSHLYSALANAGVNT ELDDEKLAKGQQLKTELWHAIEGSQISVVVESKNYIYSTWCLDELVKIMECHSSRGQVVLGDTRSTEVSHLHSALSNAGVHTEIDAG-LEKGQSLGPELLRAIEGSQIGIVVESKNYAESGWCLDELAKIAECHRSHGQVVVEDTRASFTSHIYAALQNAGIFVFKDDESLPRGRQISPSLRLAIEQSRISVVVESKNYAESWWCLKELEKIMECHRTIGRVVLEDTRKTETSHLYEVLNDKGIKTFODDKRLEYGATI PGELCKAIEESQFAIVVESENYATSRWCLNELVKIMECKTRFKQTVIEDSRYNFTANLFKALSDKGIHSFFDDDKLESGEEITATLVKAIEESRIAIVVLSPNYASSSECLDELATILHCKTKGLLVI-VDVRKTFLSHLLKALDGKS INT FIDHG-IERSRT IAPELISA IREARISIVIFSKNYASSTWCLNELVEI HKCFNDLGQMVIPDTREQFTDELYQSLRRYKIHT ERDDDELLKGKE I GPNLLRA I DQSKI YVPI I SSGYADSKWCLMELAEIVRRQEEDPRRI I L PDTRNSFVDHLSSHLLRKGIFVFNDNHELQKGESISPQLLQAIQHSRLSI IVFSENYASSTWCLDEMAAIAYCKQRSDHTVEADTRTNFTNHLLNALTQKS ISVEID-YELTKGDY IWPVLARA IEGSRVS IVVISESYASSSWCLKELEHILQFRRTRGMVVIADIGRKUSHLHSVLLQAQVKTLMKEENLQEGMELEEHMR-AIAATKIAI IVESKSYTESTCCLFQLEKI IECEETFGQI I L-

TIR-1

(continued)

TIR-2

Fig. 2. Alignment of the putative amino acid sequences of the Toll/Interleukin-1 receptor (TIR)-type resistance gene analogs (RGAs) with the TIR domains of $N$ (tobacco), L6 (flax), and RPP5 (Arabidopsis spp.). Amino acids in the conserved motifs TIR-1 (adjacent to those used to design the primer) and TIR-2 (33) are shown in bold. The regions homologous to the primers are not included. 
confirming that the TIR-containing $R$ genes are specific to dicotyledons and not found in monocotyledons (33).

The 15 RGAs were mapped at 19 loci in eight linkage groups. Eight classes were mapped in genomic regions containing QTL associated with resistance to anthracnose, ALS, and BGYMV. As mentioned above, the phenotypic variance explained by these RGAs ranged from 9.6 to $63.9 \%$. The high value of phenotypic variance explained by RGA1 and RGA7 for resistance to isolates of $C$. lindemuthianum and ALS, respectively, suggests the involvement of a major gene in these QTL. Conversely, RGA2 is linked to partial resistance to BGYMV in linkage group 4, which may represent a minor gene for resistance because of the low $r^{2}$.

This study demonstrates that QTL for resistance are associated with sequences exhibiting structural characteristics of $R$ genes (RGAs), which agrees with the hypothesis that the mechanism of qualitative and quantitative resistance may be similar (28). There are several earlier reports that demonstrate the association between RGAs and QTL $(17,43)$.

The RGAs from classes 1 and 2 were mapped at the bottom part of linkage group 11, which is associated with resistance to anthracnose. This is the same mapping region of the sequences ORF1, cD7, and cD8 obtained by Creusot et al. (10) from bean genomic and cDNA clones. ORF1, cD7, and cD8 are NBS and LRR-type sequences and represent members of a related family located in the vicinity of the $C o-2 R$ gene against anthracnose (24). Therefore, RGA1, RGA2, ORF1, cD7, and cD8 are members of a related family, although their amino acid identities are not as high as expected for sequences of the same family, suggesting a relatively rapid evolution for this $R$ gene cluster. Furthermore, assays to isolate NBS of the non-TIR class using specific primers yielded sequences of different members of the RGA1 and RGA2 classes, confirming the abundance of sequences in this family.

RGA2 also was mapped in linkage group 4 and partially contributes to resistance against the BGYMV and the 5DOM anthracnose isolate. The family of PRLJ and PRLB RGAs has been located in this region (17), associated with a major QTL that explained $70 \%$ of resistance to strain 45 of $C$. lindemuthianum and to the loci of three anthracnose-specific $R$ genes (Co-9, Co-y, and Co-z). Interestingly, BLASTN searches in the GenBank for RGA

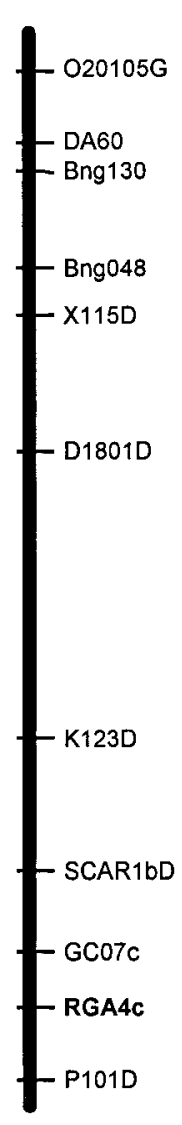

B1

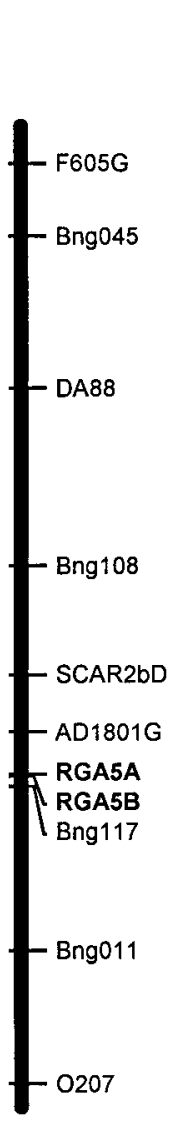

B2
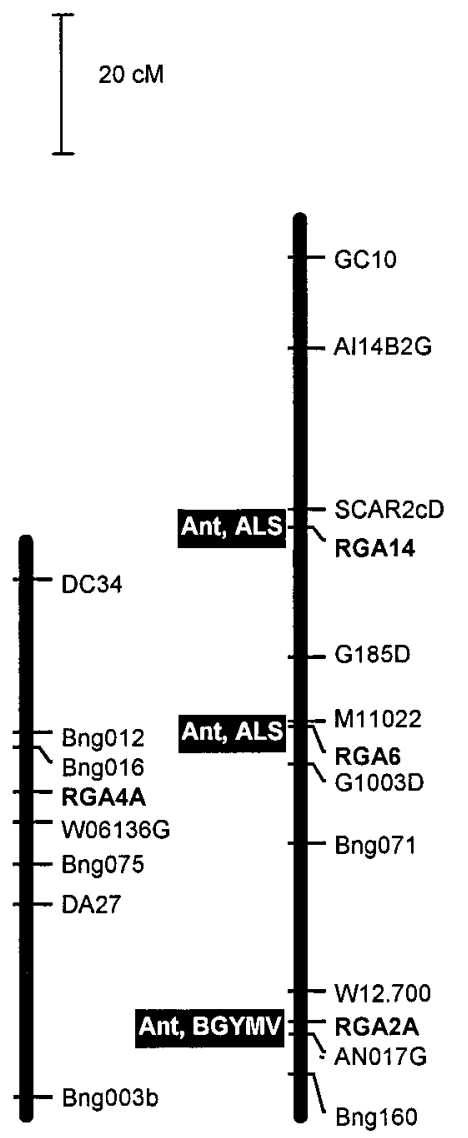

B3

B4

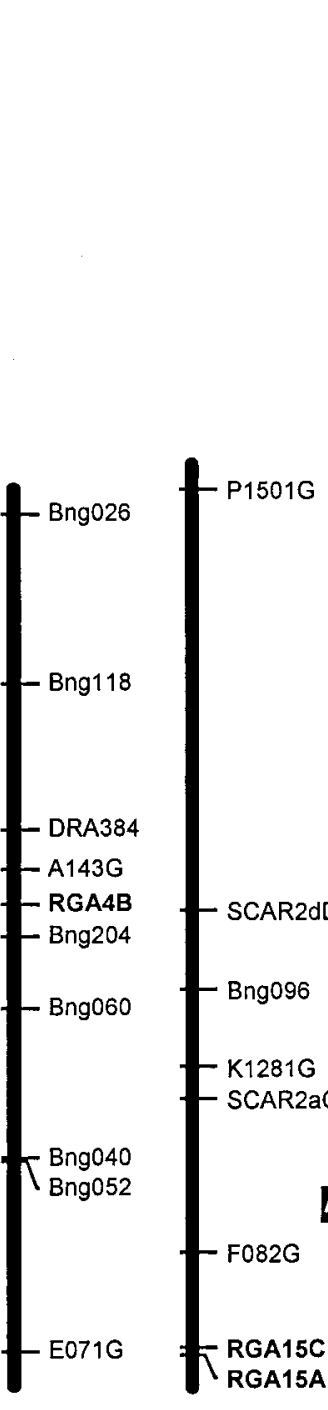

B7

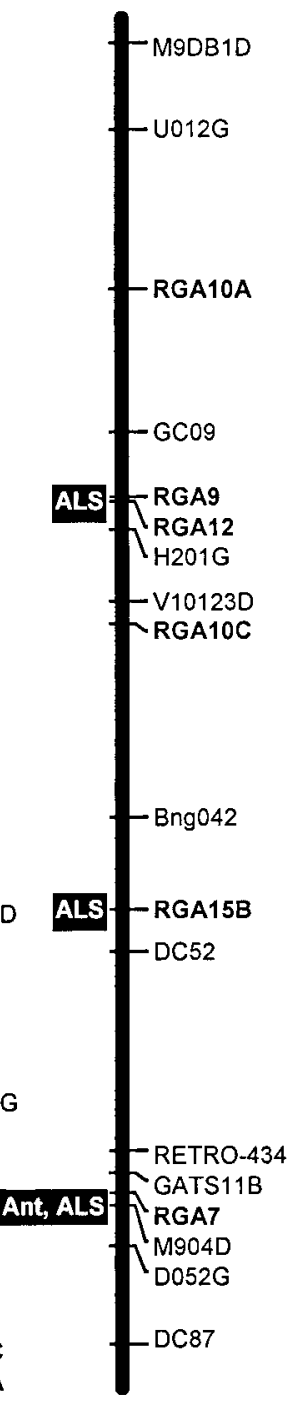

B10

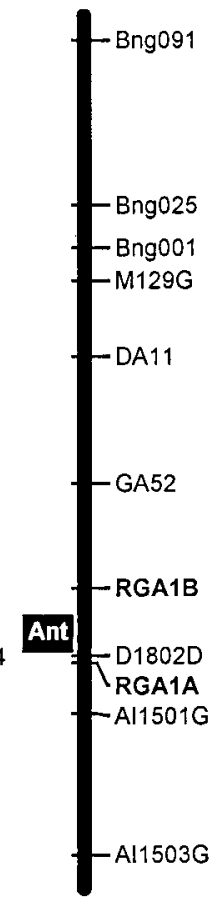

B11

Fig. 3. Linkage map of common bean from the cross DOR $364 \times$ G19833 showing the positions of resistance gene analog (RGA) loci. Only the bean linkage groups (vertical lines) containing RGAs (right, bold) along with a portion of the complete set of markers (right) are included here. Rectangles to the left represent approximate locations of quantitative trait loci $(\mathrm{QTL})$ associated with resistance to different diseases: Ant $=$ anthracnose, ALS $=$ angular leaf spot, and $\mathrm{BGYMV}=$ Bean golden yellow mosaic virus. 
classes 1 to 8 showed that only the RGA2-type sequences have been reported from bean before. RGA2 corresponds to the PRLB and the PRLJ family of RGAs. Identities between them and RGA2 range from 85 to $92 \%$ at the nucleotide level, and they are located at the same locus detected by RGA2. Taken together, these results show that these sequences belong to a family of clustered $R$ genes that contains specificities against at least two diverse pathogens (fungi and viruses). In addition, resistance to BGYMV comes from DOR364 (Andean gene pool) and to anthracnose (isolate 5DOM) from G19833 (Mesoamerican gene pool), reinforcing the idea that this cluster existed before the geographic separation of the gene pools of cultivated bean (18).

RGA7 constitutes a new cluster of RGAs on linkage group 10 and is associated to one or two major genes conferring resistance to different ALS isolates and a minor gene contributing partial resistance to anthracnose isolate 5DOM. No genes for resistance to anthracnose have been located on linkage group 10 (24); therefore, RGAs are useful to discover $R$ gene clusters that, in other ways, will be overlooked. This interesting cluster is currently being studied in depth to determine its physical structure and implications in ALS resistance.

Geffroy et al. (18) identified a major cluster containing $R$ genes that are efficient against $C$. lindemuthianum and RGAs from different gene pools of common bean. In this work, we also have detected this cluster and the isolation of different RGAs has led to the identification of another two major $R$ gene clusters that contain not only different anthracnose specificities but also determinants of resistance to the pathogens causing BGYM and ALS (virus and fungus). These results agree with previous studies showing that RGAs are part of clusters of related sequences and are co-localized with resistance loci, a pattern of genomic organization characteristic of $R$ genes. For instance, the $\mathrm{Xa21}$ locus in rice consists of at least eight sequences spanning $230 \mathrm{~kb}$ (56), the $\mathrm{M}$ locus of flax contains 15 or more sequences spread over a distance of less than $1 \mathrm{Mb}$ (4), and the Dm3 cluster of lettuce consists of at least 24 non-TIR NBS-LRR sequences that span approximately $3.5 \mathrm{Mb}$ (32). Analysis of BAC clones containing RGA7 has confirmed the multigenicity of this cluster (I. F. Acosta and C. E. López, unpublished data).

Clustered $R$ genes conferring resistance to diverse pathogens or different strains of the same pathogen also have been determined by genetic analysis (11). Thus, tight linkage between a viral and a bacterial disease resistance genes $(I$ and $R 3)$ has been detected in common bean (11). Recently, in potato, a region of $200 \mathrm{~kb}$ was demonstrated to correspond to a single resistance gene cluster of four $R$ gene-like sequences, where one corresponded to the $R x 1$ gene responsible for resistance to Potato virus $X$ and another to the nematode $R$ gene Gpa2 (54). Thus, separate members of the same $R$ gene cluster can evolve to confer resistance to unrelated pathogen species.

Several RGA classes were not linked to anthracnose, ALS, or BGYMV resistance. They could actually be part of $R$ genes conferring resistance to other isolates or even different pathogens from those tested in this study. Similar results were obtained in Arabidopsis spp., maize, and lettuce where some RGAs were not located in known $\mathrm{R}$ loci $(1,45)$. As an alternative, they could be involved in other events of plant-microbe interaction, such as symbiosis. This idea has been proposed in pea, where four RGAs were mapped in regions of the genome containing sym genes involved in the pea-rhizobia symbiosis to form nitrogen-fixing root nodules, characteristic of legumes as common bean (51). An association between the QTL for resistance to some bacterial diseases and symbiotic nitrogen fixation has been observed in common bean (36).

Conversely, not all of the disease resistance specificities data used in this study were associated to RGAs (data not shown), indicating that resistance can be determined for a different type of $R$ gene or that the set of RGAs from common bean is not yet complete. This conclusion is supported by the relatively large number of different RGAs contained in the complete genome of Arabidopsis spp. (5). Therefore, new screenings are necessary to isolate the remaining RGAs from common bean because they are a probable source of new, valuable data and markers.

RGAs are advantageous candidate genes that help to locate resistance specificities and clusters of $R$ genes. Here, we show their effectiveness in bean because some of them are associated with resistance to fungal and viral diseases. The finding that several RGAs constitute large complex families is an indicator of how difficult it is to recombine genes within clusters, one of the major concerns for breeders. Now, RGAs can be used as molecular markers in breeding; for example, in the analysis of germ plasm, as has been suggested (45). Additionally, they are good starting points for the physical characterization and isolation of $R$ gene clusters.

\section{ACKNOWLEDGMENTS}

We thank M. Rojas and J. Gutierrez for help in construction of the genetic map, J. S. Beaver for BGYMV inoculation data in our population, M. Blair for manuscript review, and V. Verdier and P. Zuluaga for helpful discussion.

\section{LITERATURE CITED}

1. Aarts, M. G. M., te Lintel Hekkert, B., Holub, E. B., Beynon, J. L., Stiekema, W. J., and Pereira, A. 1998. Identification of R-gene homologous DNA fragments genetically linked to disease resistance loci in Arabidopsis thaliana. Mol. Plant-Microbe Interact. 11:251-258.

2. Allen, D. J., Buruchara, R. A., and Smithson, J. B. 1998. Diseases of common bean. Pages 179-265 in: The Pathology of Food and Pasture Legumes. D. J. Allen and J. M. Lenné, eds. CAB International, Oxon, UK.

3. Altschul, S. F., Madden, T. L., Schäffer, A. A., Zhang, J., Zhang, Z., Miller, W., and Lipman, D. J. 1997. Gapped BLAST and PSI-BLAST: A new generation of protein database search programs. Nucleic Acids Res. 25:3389-3402.

4. Anderson, P. A., Lawrence, G. J., Morrish, B. C., Ayliffe, M. A., Finnegan, E. J., and Ellis, J. G. 1997. Inactivation of the flax rust resistance gene $M$ associated with loss of a repeated unit within the leucine-rich repeat coding region. Plant Cell 9:641-651.

5. Arabidopsis Genome Initiative. 2000. Analysis of the genome sequence of the flowering plant Arabidopsis thaliana. Nature 408:796-815.

6. Baker, B., Zambryski, P., Staskawicz, B., and Dinesh-Kumar, S. P. 1997. Signaling in plant-microbe interactions. Science 276:726-733.

7. Beebe, S., Pedraza, F., Rojas, M., Gutiérrez, J. P., and Tohme, J. 1998. A genetic map of common bean combining RFLP, RAPD, SCAR and AFLP markers. Annu. Rep. Bean Improv. Coop. 41:95-99.

8. Bent, A. F., Kunkel, B. N., Dahlbeck, D., Brown, K. L., Schmidt, R., Giraudat, J., Leung, J., and Staskawicz, B. J. 1994. RPS2 of Arabidopsis thaliana: A leucine-rich repeat class of plant disease resistance genes. Science 265:1856-1860.

9. Correa-Victoria, F. J., Pastor-Corrales, M. A., and Saettler, A. W. 1989. Angular leaf spot. Pages 59-75 in: Bean Production Problems in the Tropics. H. F. Schwartz and M. A. Pastor-Corrales, eds. Centro Internacional de Agricultura Tropical (CIAT), Cali, Colombia.

10. Creusot, F., Macadre, C., Ferrier Cana, E., Riou, C., Geffroy, V., Sevignac, M., Dron, M., and Langin, T. 1999. Cloning and molecular characterization of three members of the NBS-LRR subfamily located in the vicinity of the Co-2 locus for anthracnose resistance in Phaseolus vulgaris. Genome 42:254-264.

11. Crute, I. R., and Pink, D. A. C. 1996. Genetics and utilization of pathogen resistance in plants. Plant Cell 8:1747-1755.

12. Dickinson, M. J., Jones, D. A., and Jones, J. D. 1993. Close linkage between the $C f-2 / C f-5$ and $M i$ resistance loci in tomato. Mol. PlantMicrobe Interact. 6:341-347.

13. Dixon, M. S., Jones, D. A., Keddie, J. S., Thomas, C. M., Harrison, K., and Jones, J. D. 1996. The tomato $C f$-2 disease resistance locus comprises two functional genes encoding leucine-rich repeat proteins. Cell 84:451-459.

14. Ellis, J., Lawrence, G., Finnegan, E., and Anderson, P. 1995. Contrasting complexity of two rust resistance loci in flax. Proc. Natl. Acad. Sci. USA 92:4185-4188.

15. Freyre, R., Skroch, P. W., Geffroy, V., Adam-Blondon., A.-F., Shirmohamadali, A., Johnson, W. C., Llaca., V., Nodari., R. O., Pereira, 
P. A., Tsai, S.-M., Tohme, J., Dron, M., Nienhuis, J., Vallejos, C. E., and Gepts, P. 1998. Towards an integrated linkage map of common bean. 4. Development of a core linkage map and alignment of RFLP maps. Theor. Appl. Genet. 97:847-856.

16. Gálvez, G. E., and Morales, F. J. 1989. Whitefly-transmitted viruses. Pages 379-406 in: Bean Production Problems in the Tropics. H. F. Schwartz and M. A. Pastor-Corrales, eds. Centro Internacional de Agricultura Tropical (CIAT), Cali, Colombia.

17. Geffroy, V., Sevignac, M., De Oliveira, J. C., Fouilloux, G., Skroch, P., Thoquet, P., Gepts, P., Langin, T., and Dron, M. 2000. Inheritance of partial resistance against Colletotrichum lindemuthianum in Phaseolus vulgaris and co-localization of quantitative trait loci with genes involved in specific resistance. Mol. Plant-Microbe Interact. 13:287-296.

18. Geffroy, V., Sicard, D., de Oliveira, J. C., Sevignac, M., Cohen, S., Gepts, P., Neema, C., Langin, T., and Dron, M. 1999. Identification of an ancestral resistance gene cluster involved in the coevolution process between Phaseolus vulgaris and its fungal pathogen Colletotrichum lindemuthianum. Mol. Plant-Microbe Interact. 12:774-784.

19. Hammond-Kosack, K. E., and Jones, J. D. G. 1997. Plant disease resistance genes. Annu. Rev. Plant Physiol. Plant Mol. Biol. 48:575-607.

20. Johnson, R. 1984. A critical analysis of durable resistance. Annu. Rev. Phytopathol. 22:309-330.

21. Jones, D. A., Thomas, C. M., Hammond-Kosack, K. E., Balint-Kurti, P. J., and Jones, J. D. 1994. Isolation of the tomato $C f-9$ gene for resistance to Cladosporium fulvum by transposon tagging. Science 266:789793.

22. Jorgensen, J. H. 1992. Multigene families of powdery mildew resistance genes in locus Mla on barley chromosome 5. Plant Breed. 108:53-59.

23. Kanazin, V., Marek, L. F., and Shoemaker, R. C. 1996. Resistance gene analogs are conserved and clustered in soybean. Proc. Natl. Acad. Sci. USA 93:11746-11750.

24. Kelly, J. D., and Young, R. A. 1996. Proposed symbols for anthracnose resistance genes. Annu. Rep. Bean Improv. Coop. 39:20-23.

25. Lander, E. S., and Botstein, D. 1989. Mapping Mendelian factors underlying quantitative traits using RFLP linkage maps. Genetics 121:185199.

26. Lander, E. S., Green, P., Abrahamson, J., Barlow, A., Daly, M. J., Lincoln, S. E., and Newburg, L. 1987. MAPMAKER: An interactive computer package for constructing primary genetic linkage maps of experimental and natural populations. Genomics 1:174-181.

27. Lawrence, G. J., Finnegan, E. J., Ayliffe, M. A., and Ellis, J. G. 1995. The $L 6$ gene for flax rust resistance is related to the Arabidopsis bacterial resistance gene RPS2 and the tobacco viral resistance gene $N$. Plant Cell 7:1195-1206.

28. Lefebvre, V., and Chèvre, A.-M. 1995. Tools for marking plant disease and pest resistance genes: A review. Agronomie 15:3-19.

29. Leister, D., Ballvora, A., Salamini, F., and Gebhardt, C. 1996. A PCRbased approach for isolating pathogen resistance genes from potato with potential for wide application in plants. Nat. Genet. 14:421-429.

30. Leister, D., Kurth, J., Laurie, D. A., Yano, M., Sasaki, T., Devos, K., Graner, A., and Schulze-Lefert, P. 1998. Rapid reorganization of resistance gene homologues in cereal genomes. Proc. Natl. Acad. Sci. USA 95:370-375.

31. Martin, G. B., Brommonschenkel, S. H., Chunwongse, J., Frary, A., Ganal, M. W., Spivey, R., Wu, T., Earle, E. D., and Tanksley, S. D. 1993. Map-based cloning of a protein kinase gene conferring disease resistance in tomato. Science 262:1432-1436.

32. Meyers, B. C., Chin, D. B., Shen, K. A., Sivaramakrishnan, S., Lavelle, D. O., Zhang, Z., and Michelmore, R. W. 1998. The major resistance gene cluster in lettuce is highly duplicated and spans several megabases. Plant Cell 10:1817-1832.

33. Meyers, B. C., Dickerman, A. W., Michelmore, R. W., Sivaramakrishnan, S., Sobral, B. W., and Young, N. D. 1999. Plant disease resistance genes encode members of an ancient and diverse protein family within the nucleotide-binding superfamily. Plant J. 20:317-332.

34. Mindrinos, M., Katagiri, F., Yu, G. L., and Ausubel, F. M. 1994. The A. thaliana disease resistance gene RPS2 encodes a protein containing a nucleotide-binding site and leucine-rich repeats. Cell 78:1089-1099.

35. Nelson, J. C. 1997. QGENE: Software for marker-based genome analysis and breeding. Mol. Breed. 3:239-245.

36. Nodari, R. O., Tsai, S. M., Guzman, P., Gilbertson, R. L., and Gepts, P. 1993. Toward an integrated linkage map of common bean. III. Mapping genetic factors controlling host-bacteria interactions. Genetics 134:341350 .

37. Noël, L., Moores, T. L., van Der Biezen, E. A., Parniske, M., Daniels, M. J., Parker, J. E., and Jones, J. D. 1999. Pronounced intraspecific haplotype divergence at the RPP5 complex disease resistance locus of
Arabidopsis. Plant Cell 11:2099-2112.

38. Pan, Q., Wendel, J., and Fluhr, R. 2000. Divergent evolution of plant NBS-LRR resistance gene homologues in dicot and cereal genomes. J. Mol. Evol. 50:203-213.

39. Parker, J. E., Coleman, M. J., Szabo, V., Frost, L. N., Schmidt, R., van der Biezen, E. A., Moores, T., Dean, C., Daniels, M. J., and Jones, J. D. 1997. The Arabidopsis downy mildew resistance gene RPP5 shares similarity to the toll and interleukin-1 receptors with $N$ and $L 6$. Plant Cell 9:879-894.

40. Parniske, M., Hammond-Kosack, K. E., Golstein, C., Thomas, C. M., Jones, D. A., Harrison, K., Wulff, B. B., and Jones, J. D. 1997. Novel disease resistance specificities result from sequence exchange between tandemly repeated genes at the $C f-4 / 9$ locus of tomato. Cell 91:821-832.

41. Pastor-Corrales, M. A., Jara, C., and Singh, S. P. 1998. Pathogenic variation in, sources of, and breeding for resistance to Phaeoisariopsis griseola causing angular leaf spot in common bean. Euphytica 103:161171.

42. Pastor-Corrales, M. A., and Tu, J. C. 1989. Anthracnose. Pages 77-104 in: Bean Production Problems in the Tropics. H. F. Schwartz and M. A. Pastor-Corrales, eds. 2nd ed. Centro Internacional de Agricultura Tropical (CIAT), Cali, Colombia.

43. Pflieger, S., Lefebvre, V., Caranta, C., Blattes, A., Goffinet, B., and Palloix, A. 1999. Disease resistance gene analogs as candidates for QTLs involved in pepper-pathogen interactions. Genome 42:1100-1110.

44. Rivkin, M. I., Vallejos, C. E., and McClean, P. E. 1999. Diseaseresistance related sequences in common bean. Genome 42:41-47.

45. Shen, K. A., Meyers, B. C., Islam-Faridi, M. N., Chin, D. B., Stelly, D. M., and Michelmore, R. W. 1998. Resistance gene candidates identified by PCR with degenerate oligonucleotide primers map to clusters of resistance genes in lettuce. Mol. Plant-Microbe Interact. 11:815-823.

46. Song, W. Y., Pi, L. Y., Wang, G. L., Gardner, J., Holsten, T., and Ronald, P. C. 1997. Evolution of the rice Xa21 disease resistance gene family. Plant Cell 9:1279-1287.

47. Song, W. Y., Wang, G.-L., Chen, L. L., Kim, H. S., Pi, L.-Y., Holsten, T., Gardner, J., Wang, B., Zhai, W. X., Zhu, L. H., Fauquet, C., and Ronald, P. C. 1995. A receptor kinase-like protein encoded by the rice disease resistance gene, Xa21. Science 270:1804-1806.

48. Stavely, J. R. 1984. Genetics of resistance to Uromyces phaseoli in a Phaseolus vulgaris line resistant to most races of the pathogen. Phytopathology 74:339-344.

49. Thomas, C. M., Jones, D. A., Parniske, M., Harrison, K., Balint-Kurti, P. J., Hatzixanthis, K., and Jones, J. D. 1997. Characterization of the tomato $C f-4$ gene for resistance to Cladosporium fulvum identifies sequences that determine recognitional specificity in $C f-4$ and $C f-9$. Plant Cell 9:2209-2224.

50. Thompson, J. D., Higgins, D. G., and Gibson, T. J. 1994. CLUSTAL W: Improving the sensitivity of progressive multiple sequence alignment through sequence weighting, position specific gap penalties and weight matrix choice. Nucleic Acids Res. 22:4673-4680.

51. Timmerman-Vaughan, G. M., Frew, T. J., and Weeden, N. F. 2000. Characterization and linkage mapping of R-gene analogous DNA sequences in pea (Pisum sativum L.). Theor. Appl. Genet. 101:241-247.

52. Tohme, J., Gonzalez, D. O., Beebe, S., and Duque, M. C. 1996. AFLP analysis of gene pools of a wild bean core collection. Crop. Sci. 36:1375-1384.

53. Vanderbeek, J. G., Pet, G., and Lindhout, P. 1994. Resistance to powdery mildew (Oidium lycopersicum) in Lycopersicum hirsutum is controlled by an incompletely dominant gene $\mathrm{Ol}-1$ on chromosome 6 . Theor. Appl. Genet. 89:467-473.

54. van der Vossen, E. A., van der Voort, J. N., Kanyuka, K., Bendahmane, A., Sandbrink, H., Baulcombe, D. C., Bakker, J., Stiekema, W. J., and Klein-Lankhorst, R. M. 2000. Homologues of a single resistance-gene cluster in potato confer resistance to distinct pathogens: A virus and a nematode. Plant J. 23:567-576.

55. Whitham, S., Dinesh-Kumar, S. P., Choi, D., Hehl, R., Corr, C., and Baker, B. 1994. The product of the tobacco mosaic virus resistance gene $N$ : Similarity to toll and the interleukin-1 receptor. Cell 78:1101-1115.

56. Williams, C. E., Wang, B., Holsten, T. E., Scambray, J., daSilva, F. D. G., and Ronald, P. C. 1996. Markers for selection of the rice Xa21 disease resistance gene. Theor. Appl. Genet. 93:1119-1122.

57. Witsenboer, H., Kesseli, R. V., Fortin, M. G., Stanghellini, M., and Michelmore, R. W. 1995. Sources and genetic structure of a cluster of genes for resistance to three pathogens in lettuce. Theor. Appl. Genet. 91:178-188.

58. Yu, Y. G., Buss, G. R., and Maroof, M. A. 1996. Isolation of a superfamily of candidate disease-resistance genes in soybean based on a conserved nucleotide-binding site. Proc. Natl. Acad. Sci. USA 93:1175111756 